\title{
sciendo
}

\section{The school institution viewed as an organisation and its environment}

\author{
Katarzyna Brzychcy ${ }^{1}$ \\ WSB University in Gdańsk, al. Grunwaldzka 238 A, 80-266 Gdańsk,
}

(C) 2019 Katarzyna Brzychcy. This is an open access article distributed under the Creative Commons AttributionNonCommercial-NoDerivs license (http://creativecommons.org/licenses/by-nc-nd/3.0/

DOI 10.2478/WSBJBF-2019-0011

\begin{abstract}
Despite the fact that they are public institutions and that they seem to have the status quo of their functioning already established, schools are still exposed to various internal and external organisational changes. The article comes as a broad reflection on schools viewed as organisations and their environment, including activities that are undertaken in favour of development of such organisations. First, the article presents an explanation of the essence of an organisation. On the basis of some definitions provided by expert literature, schools are presented as organisations. Some particular attention is focused on the problem related to school environment in its micro- and macro-dimensions; it specifically refers to the establishment and maintenance of organisation-school relations. Theoretic considerations underlie the discussion of the essence of the presented survey and its results. The aim of the survey has been to identify entities that cooperate with contemporary schools and the environment in which such cooperation takes place and also to indicate the consequences that result from the interpretation of schools as organisations and their relations with the environment, viewed from the perspective of resources. The material for the research survey has been collected with the methods involving questionnaire forms and interviews. The results of the research come as a part of a more extensive research process.
\end{abstract}

Key words: organisation, environment, management, relations

\section{Introduction}

Undergoing some dynamic changes, our reality is determined by numerous factors, including flows of immigrants, demographical changes and new technologies. Under such circumstances, organisations must seek for some sources of development and competitive advantage (Skawińska, Zalewski, 2016, p. 16). Contrary to appearances, however, contemporary schools find themselves in such a situation too. Viewed as organisations, schools must meet expectations of their customers: children, their parents and their employees - teachers, administrative workers and other school stakeholders and authorities. First of all, schools must face responsibility for educating, transferring knowledge and preparing young generations to continue their education and to find their place on the labour market that is now characterised by high expectations of employers. All these facts put schools in an exceptionally difficult situation, in which they must recognise some imponderables, they must meet their own organisational needs, they must meet the needs of their customers and environment and, at the same time, they must make efforts to use their resources. The article aims at presenting the consequences of the

\footnotetext{
${ }^{1}$ kbrzychcy@wsb.gda.pl
} 
interpretation of schools as organisations and their relations with the environment, viewed from the perspective of resources. The article is based on the research survey whose partial results are presented in the text.

\section{Definition of an organisation}

Although it seems to have quite obvious semantics, the notion of organisation is perceived in many ways; it is often defined in accordance with the need related to the essence of the research process. Nevertheless, the sources of the notion should be sought in a Greek word organon, translated as creating ordered, harmonious entireties. The Oxford English Dictionary indicates Higden Rolls of 1432-50 as the earliest source in which the notion of organisation appears - in Medieval Latin, it took the form organisatio (in: Zieleniewski, 1978, p. 36).

Considering Polish science, an author and a representative of the organisation theory is Tadeusz Kotarbiński. He presents his own concept in which he states that the notion of organisation is applied to mark various ontological (semantic) categories (Kotarbiński, 1961, p. 28) that are perceived in the following ways:

Things - a strictly ontological category, only things exist. Things are objects that exist in the physical sense; they are composed of some elements, and they exist in space and time.

Feature - a property, an attribute that distinguishes a particular thing; it is ascribed to that thing regardless of any situational conditions.

Status - it is a set of features characteristic for a particular thing at a particular moment or a set of features that do not undergo any changes during the particular period of time (static events). When the status changes, it is defined as a kinetic event. A chain of events that follow one another and that are interdependent in some ways is referred to as a process.

Relation between things and parts of complex things or between features of things and events refers to the way in which one thing (feature, event) is related to another one.

All the above-mentioned elements: things, features and events can be considered as elements of a system. Such a system is connected by relations that take place amongst elements of an entirety or amongst elements and an entirety. Considered with regard to a particular aspect, it comes as a structure of that entirety. Hence, it is possible to distinguish the structure of complex things and processes. The article is focused on relations that are of key significance for the presented study.

Viewed from the perspective of the specific categorise, schools can be presented as follows:

Assets that refer, first of all, to school buildings with their equipment, such as furniture, school supplies and teaching aids, sports equipment.

An individual feature of each school is, first of all, its name and - in the case of most schools - its patron.

Considering the status, it refers to the structure of employment, the number of pupils, class timetables, meetings of the Board of Teachers - all the activities that take place during the school year and at the turn of the years.

Relations are established and maintained at several levels. They refer to all the people who are - to a various extent - involved into school life. Hence, formal, informal, indirect and direct relations are significant for school operation and commitment of all the members in the development of a particular school and its image.

Each of the above-mentioned categories, namely, things, features and events, can be considered as the elements of a system. The system is linked with relations formed amongst the elements of an entirety or between the elements and an entirety. Considered with regard to a particular aspect, it becomes a structure of the entirety. Therefore, it is possible to distinguish the structure of complex things and the structure of a process. In the article, the focus is set on relations that are of the author's main interest.

The classical ways of perceiving organisations involve the following approaches:

- objective,

- functional, 
- $\quad$ attributive.

The modern ways of perceiving organisations involve the following approaches:

- $\quad$ systemic,

- $\quad$ situational.

The objective approach presents an organisation as an entirety - a specific object that is distinguishable from its environment (e.g. by its name, logo, its place in the space: its location and address, its distinct organisational and legal form) and which has its own characteristic features. The objective meaning of an organisation refers to teams of people and institutions understood as sets of elements (sub-systems) that are distinguishable from their environment, internally systemised and related with each other. In that sense, the notion of an organisation is understood as an institution, for example: a company, a tax office, a health centre, a sport team or as an organisational process which is seen as a way of arrangement and delegation of tasks to the members of an organisation in order to achieve the assumed targets efficiently (Marek, Białasiewicz, 2008, p.15). A school is such an institution along with its name, patron, teaching staff and pupils. In previous years, organisational membership of pupils used to be manifested by a school badge worn on pupils' clothes. At present, the manifestation of pupils' school membership is limited to their school ID cards.

Considering the functional approach, an organisation comes as a set of actions that must be undertaken in order to establish an intended 'object' or an entirety. It is often said that it is simply a process of organising a particular entirety. It comes as attributing some things, phenomena, states with organisation through setting aims for people who wish to establish an organisation, or to attribute a feature of organisation to something, and then, to manage people's actions in a way that will eventually allow them to achieve the intended results (ChrisiduBudnik, Korczak, Pakuła, Supernat, 2005, p. 173). In this approach, considering their commonly accepted purpose and activities, schools are focused on education, providing classes, organising meetings of the Board of Teachers and meetings with parents in order to allow pupils to achieve the best marks.

Considering the attributive approach, an organisation is understood as an entirety composed of some parts that contribute to the success of that entirety. In this sense, an organisation becomes a feature (an attribute) of organised things. This approach is close to the understanding of the notion of a structure. An organisation is defined as a set of features that can (or cannot) be acquired through efficient (or less efficient) performance of activities that are the most important for the particular action. An organisation comes as a specific type of entirety with regard to the relation towards its own elements; it is an entirety whose all the components contribute to the success of that entirety (Kotarbiński, 1982, p. 68). At the same time, such an entirety has some influence on the success of its parts (it mainly refers to: meeting personal needs, implementing plans and satisfying ambitions of the organisation members) (Koźmiński, Obłój, 1989, p. 707). In this way, the cooperating parts of the task (specific organisational activities) streamline the whole process (they contribute to the success of all the activities undertaken by an organisation). The efficiency of the whole process proves the quality of its partial activities. The quality of a school is proved by its teachers, pupils and graduates - all its members - and also by the commitment of people who create an organisation and the environment that supports its functioning, such as parents, the Board of Education and teacher training centres. Naturally, all the above-mentioned people who create an organisation are not the only ones who contribute to its success. Material resources should also be mentioned here, with particular consideration of the quality of equipment, knowledge and financial means.

The systemic approach presents an organisation as a set of some cooperating elements (sub-systems). It is an open, social and technical system (teachers, pupils and administration) that is aim-oriented (acquisition of knowledge and implementation of curricula) and that has a specific structure or the way in which it is organised (classes, positions and interdependencies). It means that an organisation consists of technical and social elements that are related to each other. Technical elements of such a system are technology, equipment, machines, facilities and buildings; social elements include people, interpersonal relations and their symbolic products (such as aims, values, formal principles and structures). 
During the analysis of the above-mentioned questions, a definition provided by T. Kotarbiński may come to one's mind. It states that considering the attitude of its own elements towards an organisation, it is a type of entirety in which all the components contribute to its success [Kotarbiński, 1958, p. 75]. Steven R. Tannenbaum suggests another definition of a narrower spectrum. Tannenbaum understands an organisation as a type of a structure: systematisation in which all the units are mutually related and they work as a whole, however, each unit has its own task to perform ([in]: Zieleniewski, 1978, p. 71). Nevertheless, the most popular approach towards an organisation is the social approach in which groups of people behave in a purposeful way. An American sociologist, Talcott Parsons, defines an organisation as follows: an organisation comes as a social system organised in order to achieve some aims of the specific type ([in]: Zieleniewski, 1978, p. 77).

Ricky W. Griffin understands the problem in a similar way: an organisation is a group of people who cooperate with each other in a systematic and coordinated way in order to achieve a set of aims (Griffin, 1996, p. 35). An organisation can also be defined as a set of changeable processes related by various interdependencies. An organisation becomes a space where processes of integrating people around tasks and problems to be solved take place. It leads to the need of combining various contents of work, linking tasks into processes and forming an organisational structure based on those processes - not on the authority centres or functional specialisation (Sikorski, 1998, p. 23). In its material sense, an organisation is an institution or a functional group that consists of purposefully organised teams of people and objects. Real (material and physical) processes take place in an organisation along with managerial processes that involve informational and decisional actions. Lesław Martan [1991, pp. 43-51] emphasises that it is a consciously created set of components (...) and relations among those components of consciously intended variability or invariability of their own statuses. Similar to other organisations, schools are distinguished by their own resources. In literature, such resources are qualified in different ways. R. Sanchez and A. Heene distinguish assets, skills and knowledge (Sanchez, Heene, 2004, pp. 8285). K. Obłój suggests a division into source resources, operational resources and situational resources (Obłój, 2000, p. 130-131). A division presented by W.B. DeWit and R. Mayerd is also worth mentioning: material resources - they involve the so-called tangible resources, such as land, machinery, buildings, equipment, money (cash, assets of high liquidity) and non-material resources; the so-called intangible resources, such as relation resources, for example, relations with suppliers, customers, environment, reputation and brand awareness; and skills that refer to knowledge, innovative capabilities with regard to products and processes, integration skills ( DeWit, Mayerd, 1991, p. 201).

Whilst analysing all the above-mentioned definitions and observations on an organisation, it is impossible to discuss all the achievements in this field. However, the key concept refers to resources owned by an organisation, such as relations, affinities and connections, understood as a space amongst people, objects and groups, which is identified by attitudes, communication, emotions and commitment. Relations trigger various positive activities that develop an organisation and its members; negative activities can lead to a decline of an organisation in the worst case. For schools, internal relations are of special importance, but it should be emphasised that relations with their environment are also significant.

\section{Environment of an organisation}

For an organisation, its environment is of two-fold nature. On the one hand, it comes as everything that provides an organisation with capabilities to survive on the market - for schools, it refers to pupils, immigrants, sources of additional funds, places for development and improvement of qualification. On the other hand, it is also a source of threats, such as unfavourable demographical changes, new requirements stated in legal regulations, new technologies and competition related to the establishment of new schools (Johnson, Scholes, Whittington 2010, p. 47). Considering the character of relations observed between the environment and a particular object, it is possible to discuss macro-environment, which is distant and general, and micro-environment also referred to as direct, competitive or task-related environment (Małkowska-Borowczyk 2011, p. 121). The environment of a company an entity, for example, a school - can be seen as a set of elements that are not the components of such an entity but are related to it in certain ways (Bielski 1997, p. 126). Hence, an organisation operates in an environment that 
includes factors affecting its functioning and development. Such factors are, amongst others, cultural factors that come as a system of standards and values followed in a particular community, social and political factors that are manifested in social needs, priorities and principles of satisfying such needs and a system of economy management and state administration (Lemańska-Majdzik 2013, p. 103). At the commencement of its operation as an organisation, each organisation, including schools, immediately enters its macro-environment that can be defined as a set of operational conditions for all the organisations at a particular time and in a particular space (Rozum 2013, p. 62). Macro-environment is defined as a set of all the units, organisations and factors that affect the operation of an organisation and its performance. In order to be successful, an organisation must constantly run the process of identification and it must respond to tendencies observed in its macro-environment as well as to new unsatisfied needs. Therefore, this is a field where the search for market opportunities for an organisation should begin and where some possible threats can occur (Wolański 2013, p. 49). The specific character of macroenvironment results in the fact that the processes that take place there do not directly affect the achievement of aims set by an organisation; they form conditions that are significant for the success in business and, in the case of schools, the success in achieving aims that have been defined for them (Jelonek 2009, p. 14). As contemporary schools indicate, such conditions related to their macro-environment include access to the European funds, a high number of pupils who do not speak Polish (foreigners) and cooperation with foreign schools. These are the fields where schools can find advantages. They provide valuable opportunities to the particular members of an organisation - a school (through the satisfaction of their needs and individual aspirations) - as well as to the entire organisation viewed as a system. Micro-environment is closer to an organisation, and it can be more affected by that organisation. Micro-environment includes customers, competitors, suppliers, intermediaries and some public institutions, such as mass media (Budzik, Zachorowska 2016, p. 92).

The environment of schools and other organisations constantly affects them with various intensities; however, specialists state that it gains more and more significance, and it largely determines the behaviour of organisations, including schools. Hence, it is obvious that in order to survive and, first of all, to develop, it is necessary for an organisation (a school) to recognise its own environment, including the particular elements of macro- and microenvironment. As it has been already mentioned, environment may have some positive or negative influence. It is possible to cooperate with environment and also to compete with it. Schools generally cooperate with their environment, but they compete with other schools of the same level. In order to achieve their aims, modern schools are forced to establish efficient relations with their environment, especially in a situation when school candidates look for organisations where pupils are particularly successful. Such relations must be characterised by flexibility - skills that enable an organisation to adjust itself to dynamically changing conditions of its environment with the consideration of the fact that such a process is not characterised by a strict, one-direction interaction (Cyfert, Krzakiewicz 2014, p. 13). Hence, the functioning of a school largely depends on relations with its environment and also on internal organisational relations.

\section{Methodological assumptions of the author's own research}

The results of the survey discussed in the article come as a part of some more extensive research on the functioning of schools viewed as organisations. The subject of the research refers to school resources, the methods applied to acquire them and to use them by schools. The research survey has been aimed at answering two research questions: how are resources created by schools viewed as organisations? How are school resources used for the development of internal and external relations of an organisation? The research survey has been carried out at 30 primary and secondary schools in the county of Gdańsk, with the use of two research tools, namely, an interview and a questionnaire form. Between June 2017 and November 2017, the questionnaire forms were completed by 120 teachers, including representatives of school authorities. There were also interviews conducted with 30 teachers at that time. It has been assumed that as an organisation that operates in its micro- and macro-environment in order to meet expectations and needs of pupils and their parents, a school constantly undertakes new forms of activities to make the process of education more attractive and to present the curriculum materials in conditions that are as actual as possible. Hence, the usefulness of such materials can be proved in everyday life. 
In order to achieve the above-mentioned aim, the activities of schools have been identified based on initiatives that are additionally undertaken by schools; then school macro- and micro-environment has been identified, and the relations that allow schools to implement some additional initiatives have been indicated. At the same time, some emphasis has been laid on some selected elements that support the development of positive, valuable relations, such as communication, commitment, ingenuity, knowledge sharing and mutual support.

\section{The results of the research}

At first, it should be emphasised that the teachers participating in the survey have willingly answered all the questions. One of the questions in the survey refers to the access to information about events taking place at school. It is interesting that regardless of the sizes of the surveyed schools, the full access to all the information about events taking place at school is not provided (Table 1). The places where such information is available and are used by the teachers are (by the frequency of their mentioning) a notice board at the Staff Room, word-of-mouth, e-mail, meetings of the Board of Teachers, learning management system (LMS) and posters placed in the school corridors. The fact that not all the communication channels are used is exacerbated by the fact that not all the teachers inform about their additional initiatives.

The teachers try to inform about events taking place at school; however, there are some situations in which they inform about an event after it has ended (15.8\%). When asked why it is so, they claim that they forgot about it because of other responsibilities at that time, that it was not anything important or that they had already had a group of children and they did not need any help from other people. Such behaviour is not favourable for the development of relations, cooperation and good atmosphere. Still, the surveyed teachers do not see anything wrong in such a situation. They admit that they are not interested in all the initiatives taking place at their schools $(41.6 \%)$.

The lack of full information, the attitudes that lack commitment and the fact that the teachers are involved only in a narrow scope of activities weaken relations and resources that can be developed by an organisation. Considering the initiatives undertaken by schools, the results of the research present them in very positive light. Schools are active in various fields of activities, and they often go beyond their limits.

In order to obtain some information about the activities undertaken at schools, one of the questions in the survey refers to the thematic fields in which schools try to interest their pupils (Table 2). The choice of thematic fields has mainly resulted from the interests declared by their pupils $(56.6 \%)$, interests declared by the teachers and possibilities of using one's personal acquaintances $(30.8 \%)$ and parents $(8.3 \%)$. All the schools participating in the survey indicate more than 10 fields of school activities. All the answers are grouped by the thematic fields:

1. Ecological and health education, safety;

2. Sport and recreation;

3. Social and civil activity;

4. Entrepreneurship and initiative;

5. Cultural awareness and expression;

6. Development;

7. Communication in foreign languages;

8. Mathematical, scientific and technical competences;

9. IT competences.

Table 1. Knowledge about initiatives taking place at school

\begin{tabular}{l|c|c}
\hline Knowledge about events organised at school & T & \% \\
\hline I know about all the initiatives undertaken at school & 36 & 30 \\
I know about some selected initiatives taking place at school & 50 & 41,6
\end{tabular}


I am not interested in any other initiatives but my own ones

I do not participate, I do not organise and I am not interested in any initiatives Total

Source: the author's own work.

All the above-mentioned fields have their internal initiatives that come as their components. The presented results are not summed up because the respondents have mentioned all the activities taking place at their schools that they have been aware of. The initiatives listed by the respondents include not only their own initiatives but also those of other teachers.

Table 2. Fields of activities at schools

\begin{tabular}{|c|c|c|c|}
\hline Field & Specification & $\mathbf{T}$ & $\%$ \\
\hline $\begin{array}{l}\text { Ecological and Health } \\
\text { Education }\end{array}$ & $\begin{array}{l}\text { Healthy lifestyle } \\
\text { Ecological education } \\
\text { Sustainable development } \\
\text { First aid school clubs }\end{array}$ & 48 & 40 \\
\hline Sport and Recreation & $\begin{array}{l}\text { Maritime education } \\
\text { School sports clubs } \\
\text { Sports events } \\
\text { Recreational events } \\
\text { Sightseeing trips }\end{array}$ & 120 & 100 \\
\hline Social and Civil Activity & $\begin{array}{l}\text { Voluntary service } \\
\text { Local community } \\
\text { Multi-culturalism } \\
\text { European school clubs } \\
\text { Oxford debates }\end{array}$ & 67 & 55.83 \\
\hline $\begin{array}{l}\text { Entrepreneurship } \quad \text { and } \\
\text { initiative }\end{array}$ & $\begin{array}{l}\text { Students' projects } \\
\text { Cooperatives/students' companies } \\
\text { Financial education } \\
\text { Creative thinking } \\
\text { Career counselling/school information and } \\
\text { career centres }\end{array}$ & 110 & 91.6 \\
\hline $\begin{array}{l}\text { Cultural Awareness and } \\
\text { Expression }\end{array}$ & $\begin{array}{l}\text { Drama classes } \\
\text { Film classes } \\
\text { Recitation and literature school clubs } \\
\text { Music clubs } \\
\text { Dancing classes } \\
\text { Native language } \\
\text { History }\end{array}$ & 119 & 98.3 \\
\hline Development & $\begin{array}{l}\text { Learning skills } \\
\text { Projects } \\
\text { Development of talents } \\
\text { Psychological therapies } \\
\text { Pedagogical therapies }\end{array}$ & 120 & 100 \\
\hline $\begin{array}{l}\text { Communication in Foreign } \\
\text { Languages }\end{array}$ & $\begin{array}{l}\text { International cooperation } \\
\text { Students exchange } \\
\text { Teachers exchange } \\
\text { Bilingual classes }\end{array}$ & 76 & 63.3 \\
\hline $\begin{array}{l}\text { Mathematical, Scientific and } \\
\text { Technical Competences }\end{array}$ & Scientific experiments & 68 & 56.6 \\
\hline
\end{tabular}




\section{IT Competences}

Source: the author's own work.

$$
\begin{aligned}
& \text { Digital skills } \\
& \text { Robotics } \\
& \text { New media } \\
& \text { Coding }
\end{aligned}
$$

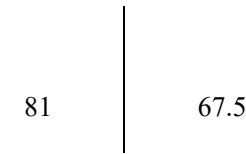

The fields of school activities presented above are implemented in the form of extra-curricular activities, participation in various competitions and contests, projects co-funded by the European Union, Boards of Parents, own means or means provided by sponsors. Some teachers (15\%) claim that they have implemented all the initiatives by themselves; however, most of them have mentioned their teacher colleagues or they have indicated some specific external institutions. The institutions mentioned by the respondents are presented in Table 4 . They are arranged into three categories:

Institutions supporting schools - those that have been established strictly in order to participate in school life through their tasks. Amongst institutions supporting schools are also institutions that participate in school life even though there are no tasks oriented towards support for schools in their core activities. They provide support that involves ad-hoc immediate education and prevention. The support of that type does not refer exclusively to teachers and students, but it also involves their parents and guardians.

Entities cooperating with schools - institutions that do not have any tasks oriented directly toward cooperation with schools in the scope of their activities but because of some preventive and educational tasks and also some tasks that are related to children, they do cooperate with schools.

\begin{tabular}{|c|c|c|}
\hline $\begin{array}{c}\text { Institutions supporting } \\
\text { schools }\end{array}$ & Entities cooperating with schools & Cooperation with other schools \\
\hline 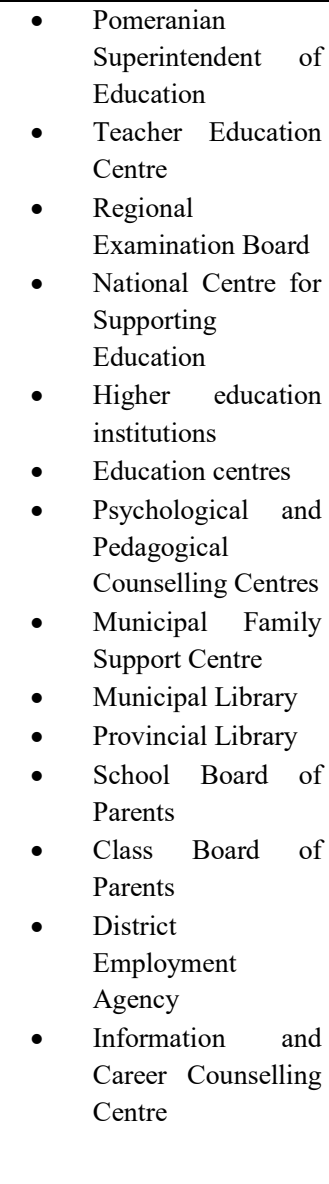 & 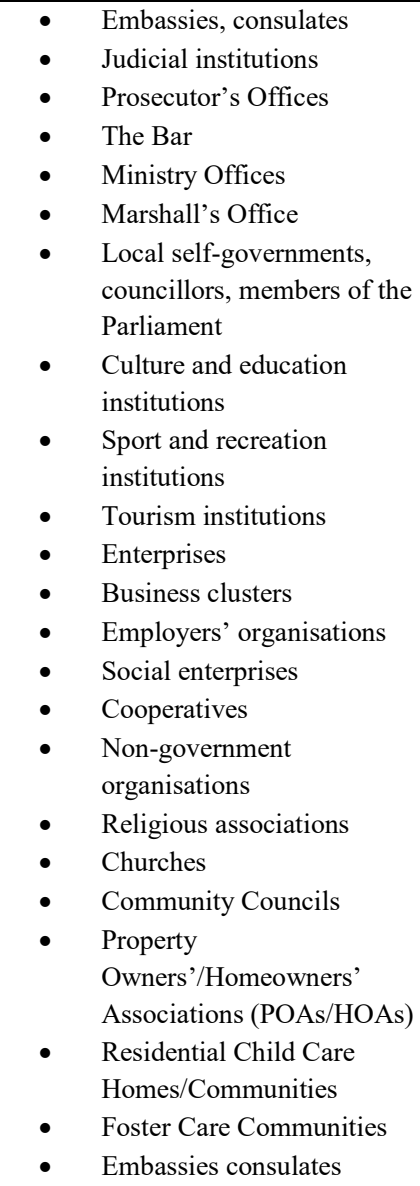 & $\begin{array}{ll}\text { - } & \text { Local primary schools } \\
\text { - } & \text { Provincial primary } \\
\text { - } & \text { Primary schools } \\
\text { - } & \text { Foreign schools from the } \\
\text { - } & \text { FU member states } \\
\text { - } & \text { outside of the European } \\
\text { - } & \text { Snion schools from } \\
\text { - } & \text { International } \\
\text { - } & \text { Ambanady, konsulaty } \\
\text { - } & \text { Embassies, consulates } \\
\text { - } & \text { Non-public schools } \\
\text { Vocational schools }\end{array}$ \\
\hline
\end{tabular}

Cooperation with other schools - it refers to cooperation with other schools in all the fields of their functioning. This group includes organisations that support foreign cooperation.

Table 3. Institutions that support and cooperate with schools 


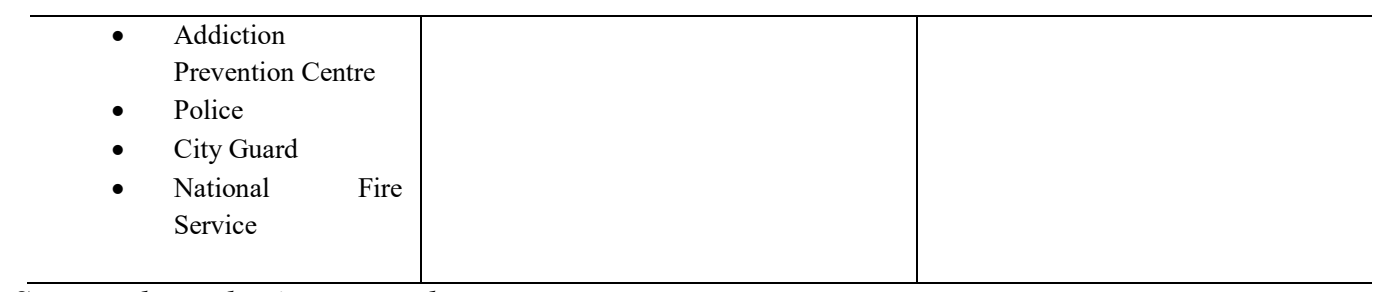

Source: the author's own work.

As indicated in Table 3, there is an extensive and differentiated scope of institutions. It seems that each field is covered and pupils are provided with some unique opportunities to meet practitioners. However, it is not quite so. It turns out that in the case of $86 \%$ of the respondents, the established relations and undertaken initiatives, such as meetings and visits at companies, result from some direct personal relations. All the teachers participating in the survey have mentioned that fact. The main drawback of the initiatives undertaken by teachers refers, first of all, to the fact that they are based on independent private relations established by teachers. When particular teachers leave their schools, the cooperation is usually finished $(92.5 \%)$.

\begin{tabular}{|c|c|c|}
\hline Continuation of cooperation with the environment & $\mathbf{T}$ & $\%$ \\
\hline Cooperation is continued & 2 & 1.7 \\
\hline $\begin{array}{l}\text { It depends on the partner and on the fact whether the } \\
\text { responsibility for the continuation of cooperation has been } \\
\text { passed on to someone else }\end{array}$ & 7 & 5.8 \\
\hline $\begin{array}{l}\text { Cooperation is finished as soon as the teacher responsible } \\
\text { for it leaves school }\end{array}$ & 111 & 92.5 \\
\hline Total & 120 & 100 \\
\hline
\end{tabular}

Source: the author's own work.

Such a situation is not good and it would be worth taking care of proper continuation of the relations that have been established. Such superficiality and ease seem to result from two main reasons: the first one is the lack of formal institution of the cooperation and the second one is the lack of strategic documents stating the lines for school development that would allow specific school partners to be treated selectively and to increase their significance and the importance of joint activities with regard to the specific school character. More mutual engagement into long-term cooperation provides real chances for its new and deeper dimensions.

Describing the fields of school activities, the teachers have referred to the school environment. It has allowed the author to suggest a systematisation of the school environment, according to a new structure: micro-, mezzo- and macro-environment, as presented in Table 5.

- Micro-environment includes entities that are directly related to schools because of their tasks;

- Mezzo-environment includes entities that support schools because their tasks are related to school activities and pupils. It is possible to state that pupils are customers of those entities and of their schools;

- Macro-environment includes institutions that are, by assumption, not directly or indirectly oriented towards cooperation with pupils and their schools.

In addition, there have been three fields presented from close and distant perspectives. In such a distinction, the direct cooperation with schools and levels of impact exerted on schools have been taken into consideration. Internal school organisations that decide about activities undertaken at school (the Board of Parents), organisations that undertake cooperation with schools and benefit from such cooperation (higher education institutions) and entities that are based in the area of school (Community Councils) form a close perspective. A distant perspective is formed by organisations whose tasks are related to schools but are based 
outside (the Superintendent of Education); organisations that can support schools with their knowledge and can help to acquire skills needed in the future (the District Employment Agencies), however, their operations are not directly focused on pupils; and institutions that are generally not focused on any specific schools (Ministries).

\begin{tabular}{|c|c|c|c|}
\hline Environment & Micro-environment & Mezzo-environment & Macro-environment \\
\hline Close & (1) & $\begin{array}{l}\text { Higher education institutions } \\
\text { Education centres } \\
\text { Psychological and Pedagogical } \\
\text { Counselling Centres } \\
\text { Municipal Family Support Centre } \\
\text { Municipal Library } \\
\text { Provincial Library }\end{array}$ & $\begin{array}{l}\text { Community Councils } \\
\text { Property } \\
\text { Owners'/Homeowners' } \\
\text { Associations (POAs/HOAs) } \\
\text { Enterprises } \\
\text { Business clusters } \\
\text { Employers' organisations } \\
\text { Social enterprises } \\
\text { Cooperatives } \\
\text { Non-government } \\
\text { organisations } \\
\text { Religious associations } \\
\text { Churches } \\
\text { Residential Child Care } \\
\text { Homes/Communities } \\
\text { Foster Care Communities } \\
\text { Embassies consulates }\end{array}$ \\
\hline Distant & $\begin{array}{l}\text { Pomeranian } \\
\text { Superintendent of } \\
\text { Education } \\
\text { Teacher Education } \\
\text { Centre } \\
\text { Regional Examination } \\
\text { Board } \\
\text { National Centre for } \\
\text { Supporting Vocational } \\
\text { and Adult Education }\end{array}$ & $\begin{array}{l}\text { District Employment Agency } \\
\text { Information and Career Counselling } \\
\text { Centre } \\
\text { Addiction Prevention Centre } \\
\text { Police } \\
\text { City Guard } \\
\text { National Fire Service } \\
\text { Culture and education institutions } \\
\text { Sport and recreation institutions } \\
\text { Tourism institutions }\end{array}$ & $\begin{array}{l}\text { Ministry Offices } \\
\text { Marshall's Office } \\
\text { Local self-governments, } \\
\text { councillors, members of the } \\
\text { Parliament } \\
\text { Judicial institutions } \\
\text { Prosecutor's Offices } \\
\text { The Bar }\end{array}$ \\
\hline
\end{tabular}

Source: the author's own work.

Undoubtedly, the study requires further attention and research but it still seems to provide a picture of an organised system of the school-organisation environment.

\section{Conclusions}

It is certain that schools are organisations that have their own environment. As Elliot Aronson states, people are social beings. Entering into relations inside and outside an organisation, people form a space for their own development and improvement and for the development of an organisation to which they belong and identify themselves with (Bruning, Ledingham, 1999, p. 158). The aim of the article is to present the consequences that can be observed when schools are viewed as organisations and relations with their environment, with the consideration of the aspect related to resources. The partial results of the research survey that has been carried out with the use of the methods based on a questionnaire form and an interview allow the author to draw the following conclusions: information given by teachers about their initiatives, which is put in a visible place, should provide as many details as possible to avoid additional questions. It would be advisable to develop a platform for information exchange and cooperation because it often happens that a school cooperates with the same institution through several teachers who are unaware of cooperation run by their colleagues. The above-mentioned platform for information exchange would allow interested parties to continue their cooperation even when a teacher who is responsible for the cooperation with a particular institution has left school. 
Another conclusion refers to the need of specialisation and definition of levels of cooperation taking place between schools and institutions. It refers to long-term cooperation with institutions that can become one of the pillars for the class specialisation profiles implemented at schools. Sporadic meetings with institutions will eliminate random meetings where irrelevant topics are discussed. The last conclusion comes as a suggestion that refers to the establishment of cooperation run by thematic teams related to the class specialisation - not topics. Such teams could involve teachers who run particular classes of specialised profiles. As a result, classes of various levels could mutually educate themselves by exchanging students' and teachers' experience. Such activities will provide a chance for relations established by the organisation participants to go beyond their exclusively spontaneous character. Such an organisation and relations must be properly managed in order to become a resource of that organisation. Such an approach will cover the environment and institutions that form it. Schools can purposefully affect their environment and benefit from it. It will allow schools to develop and to become more competitive with regard to other schools.

The subject of the article has not been exhausted, and it definitely requires further in-depth studies. Hence, the article seems to be a good starting point for further scientific research.

\section{References}

Bielski M., Organizacje: istota, struktury, procesy, Wydawnictwo Uniwersytetu Łódzkiego, Łódź 1997.

BruningJohn S. D., Ledingham A., Relationships between organizations and publics: Development of a multidimensional organization-public relationship scale, "Public Relations Review", 1999, Vol. 25, Issue 2.

Budzik T., Zachorowska A., Rola otoczenia w strategii organizacji, „Zeszyty Naukowe Politechniki Częstochowskiej”, „Zarządzanie”, 2016, No. 24 vol.1.

Chrisidu-Budnik A., Korczak J., Pakuła A., Supernat J., Nauka organizacji i zarzadzania, Kolonia, Wrocław 2005.

Cyfert S., Krzakiewicz K., Wpływ mechanizmów odnowy organizacyjnej na skuteczność zmian w modelach biznesu polskich przedsiębiorstw, [in:] Stabryła A., Małkus T. (ed.), Strategie zarzadzania organizacjami w spoteczeństwie informacyjnym, seria: Encyklopedia Zarządzania, Mfiles.pl, Kraków 2014.

DeWit W.B., Mayer R., Strategy Synthesis. Resolving Strategy Pardoxes to Create Competitive Advantage, International Thomas Business Press, London 1999.

Fazlagić, J. A. (2005). Polska szkoła jako organizacja ucząca się. e-mentor (3).

Griffin R. W., Podstawy zarządzania organizacjami, PWN, Warszawa 1996.

Jelonek D., Strategiczna harmonizacja monitorowanie otoczenia i technologii informacyjnej w przedsiębiorstwie. Studium metodologiczno-empiryczne, Wydawnictwo Politechniki Częstochowskiej, Częstochowa 2009.

Johnson G., Scholes K., Whittington R., Podstawy strategii, Polskie Wydawnictwo Ekonomiczne, Warszawa 2010.

Kotarbiński T., Elementy teorii poznania, logiki formalnej i metodologii nauk, Zakład Narodowy im. Ossolińskich, Wrocław 1961.

Kotarbiński T., Traktat o dobrej robocie, Ossolineum, Warszawa 1982.

Kotarbiński T., Traktat o dobrej robocie, Zakład Narodowy im. Ossolińskich, Wrocław - Warszawa 1958.

Koźmiński A.K., Obłój K., Zarys teorii równowagi organizacyjnej, PWE, Warszawa 1989.

Lemańska-Majdzik A., Otoczenie a funkcjonowanie przedsiębiorstwa - wybrane aspekty, [in:] Korombel A. (ed.), Wspótczesne problemy zarzadzania przedsiębiorstwami. Teoria i praktyka, Sekcja Wydawnictw Wydziału Zarządzania Politechniki Częstochowskiej, Częstochowa 2013.

Lenart, R. (2014). Zarzadzanie wiedza w tworzeniu konkurencyjności szkoły. ABC a Wolters Kluwer business.

Małkowska-Borowczyk M., Otoczenie jako źródto problemów i presji na wybory strategiczne przedsiębiorstw, [in:] Urbanowska-Sojkin E. (ed.), Podstawy wyborów strategicznych w przedsiębiorstwach, PWE, Warszawa 2011.

Marek S., Białasiewicz M., Podstawy nauki o organizacji, PWE, Warszawa 2008.

Martan L., W sprawie tożsamości nauk o kierowaniu organizacjami, „Organizacja i Kierowanie” 1991, no. 2 (64).

Obłój K., Strategia sukcesu firmy, PWE, Warszawa 2000,

Rozum K., Przeglad koncepcji $i$ wybranych technik zarzadzania strategicznego, [in:] Wawak S. (ed.), Metody i techniki diagnozowania w doskonaleniu organizacji, Mfiles.pl, Kraków 2013.

Sikorski C., Ludzie nowej organizacji. Wzory kultury organizacyjnej wysokiej tolerancji niepewności, Wydawnictwo Uniwersytetu Łódzkiego, Łódź 1998. 
Skawińska, E., Zalewski, R.. Konkurencyjność - kluczowe czynniki sukcesu przedsiębiorstw w XXI w. „Przegląd Organizacji”, 2016, no. 3.

Sanchez R., Heene A., The New Strategic Management. Organization, Competition and Competence, John Wiles \& Sons, New York 2004.

Wolański R., Wplyw otoczenia finansowego na konkurencyjność małych i średnich przedsiębiorstw, Wolters Kluwer, Warszawa 2013.

Zieleniewski J., Organizacja zespołów ludzkich. Wstęp do teorii organizacji i kierowania, PWN, Warszawa 1978. 